pesquisa em administração

1. Introdução;

2. A genealogia do poder em Michel Foucault;

3. Metodologia;

4. Conclusōes.

\section{Poder e controle na grande empresa industrial: alternativas metodológicas para a pesquisa qualitativa}

Fernando Coutinho Garcia Do CMA/Face/UFMG

Marco Aurélio Rodrigues Do CMA/Face/UFMG

Reynaldo Maia Muniz Do CMA/Face/UFMG

'Para haver lucro é preciso haver subpoder. E preciso que, ao nivel mesmo da existência do homem, uma trama de poder microscópico, capilar, se tenha estabelecido, fixando os homens ao aparelho de produçäo, fazendo deles agentes de produção, trabalhadores. A ligaçāo do homem ao trabalho é sintética, é uma ligação openada pelo poder que descrevi há pouco e não do que é chamado tradicionalmente de poder politico; não se trata de um aparelho de Estado, nem da classe no poder; mas do conjunto de pequenos poderes, de pequenas instituiçōes situados em um nivel mais baixo."

\section{(Michel Foucault)}

"De um modo geral, os pensadores desconhecem as dificuldades que encontrarão para fazer seu sistema 'pegar', eles ignoram que haverá sempre formas de escapar às malhas da rede e que as resistências desempenharão seu papel (. . .)
O próprio discurso penitenciário se desenrola como se não houvésse ninguém frente a ele, a não ser uma tábula rasa, a não ser pessoas a reformar e a devolver em seguida ao circuito da produção. $\mathrm{Na}$ realidade existe um material - os detentos que resiste incrivelmente. $O$ mesmo poderia ser dito em relação ao taylorismo. Esse sistema é uma extraordinária invenção de um engenhsiro que quer lutar contra a vagabundagem, contra tudo o que diminui o ritmo da produção. Mas pode-se colocar a questão: o taylorismo algum dia realmente funcionou?"

(Michelle Perrot)

\section{INTRODUÇĀO}

Quem detém o poder? Qual estratégia adotar para assumir o poder? Qual a fonte do poder? Essas perguntas e inúmeras outras dessa mesma natureza estamos acostumados a ouvir e a ler nos velhos e "novos" manuais marxistas de teoria das organizaçoes. Por outro lado, Weber dedicou uma parte substancial de sua obra para explicar o funcionamento do poder, a natureza da autoridade $;_{;}^{1}$ os funcionalistas não inovaram, pelo contrário, sofisticaram o conceito, utilizando, na maioria das vezes, uma bateria de testes estatísticos, correlaçðes, regressðes etc., ${ }^{2}$ ignorando a história e mergulhando naquilo que Mills, brilhantemente, adjetivou de empirismo abstrato; ${ }^{3}$ enfim, "de uma maneira geral, os mecanismos de poder nunca foram muito estudados na história. Estudaram-se as pessoas que detiveram o poder. Era a história anedótica dos reis, dos generais. Ao que se opôs a história dos processos, das infra-estruturas econômicas. A estas, por sua vez, se opôs uma história das instituiçбes, ou seja, do que se considera superestrutura em relação d̀ economia. Ora, o poder em suas estratégias, ao mesmo tempo gerais e sutis, em seus mecanismos, nunca foi estudado" (Foucault, 1979, p. 141).

Eis nossos objetivos: sustentar que o poder está disseminado em todo o corpo social; desmitificar o velho slogan marxista de dominantes sendo eternamente dominantes e dominados sendo eternamente dominados (slogan esse que virou religiáo, fé etc., pois qualquer invèstigação empirica em organizaçóes parte desse pressuposto como algo ex-ante!);" ter a "visao do poder, nao como simples aparato e instrumento, subordinado a uma vontade de classe qualquer, mas, antes de mais nada, como forma constitutiva da sociedade em suas mínimas articu. laçōes - e nada mais do que estas" (Montanari, 1980, p. 79-80); procurar compreender e estudar a estrutura de poder das organizaçóes, em particular a organização industrial brasileira, e procurar entender "o que significa estar por baixo" ou "o que significa estar por cima"; investigar empiricamente, no âmbito das organizaçóes, $c 0$ mo "o dominante numa regiāo do sistema pode ser do- 
minado em outra. E o dominado numa área da sociedade pode ser dominante noutra" (Da Matta et aiii, 1982, p. 20; grifo nosso).

Enfim, como conlui o próprio autor, "tudo indica essas fantásticas possibilidades tão familiares a todos nós, de ser patrão e cliente ao mesmo tempo, desde que se olhe para baixo ou para cima; desde que se esteja em casa, na rua ou no local de culto religioso" (Da Matta et alii, 1982, p. 20). Acrescento: a fábrica - como se distribui o poder entre o supervisor, o contramestre e 0 operário? Quem é o dominante e o dominado naquele momento histórico e naquele departamento específico? E quando o operário é promovido a contramestre, como seus colegas vão tratá-lo: dominante ou dominado? Numa situação de greve, num país democrático, quem é o dominante no interior de uma determinada unidade fabril? E na ocortência da "operação tartaruga" (tão comum nas nossas indústrias), quem é o dominante? Será o operário ou os técnicos do departamento de "tempos e movimentos"'? Resumindo nossos objetivos: estudar a "microfísica do poder"; estudar suas estratégias, lutas e mecanismos; desenvoiver um quadro teórico-metodológico para testá-lo empiricamente no interior de grandes organizações industriais.

\section{A GENEALOGIA DO PODER EM MICHEL FOUCAULT}

\subsection{Sobre o conceito de poder}

Duas observaçôes iniciais: a eficácia de apreender e destrinchar os complexos mecanismos de poder que permeiam a sociedade em geral e as organizaçбos em particular reside em procurar localizar o discurso e a ação desses mecanismos. fora do aparelho de Estado; nas instituiçōes, a todo momento, estamos presenciando estratégias, combates e lutas. É necessário mapeá-los, desvendar toda a sutileza que os caracteriza.

"Desde o momento em que se quer fazer uma história que tenha um sentido, uma utilizaçăo, uma eficácia política, só se pode fazê-la corretamente sob a condiçăo de que se esteja ligado, de uma maneira ou de outra, aos combates que se desenrolam neste domínio (...) Não tenho de forma alguma a intenção de diminuir a importância e a eficácia do poder de Estado. Creio simplesmente que, de tanto se insistir em seu papel exclusivo, corre-se o risco de nao dar conta de todos os mecanismos e efeitos de poder que năo passam diretamente pelo aparelho de Estado, que muitas vezes o sustentam, o reprođuzem, elevam sua eficácia ao máximo. A sociedade soviética é um exemplo de aparelho de Estado que muda de mãos e que mantém as hierarquias sociais, a vida familiar, a sexualidade, o corpo quase como eram em uma sociedade do tipo capitalista" (Foucault, 1979, p. 156-61).

E necessário, antes de mais nada, estudar o poder independentemente de teorias globais e universalizantes, ou seja, privilegiando a genealogia: "Delineou-se assim o que se poderia chamar de genealogia, ou melhor, pesquisas genealógicas múltiplas, ao mesmo tempo redescoberta exata das lutas e memória bruta dos combates. E esta genealogia, como acoplamento do saber erudito e do sa. ber das pessoas, só foi possível e só se pode tentar realizá-la à condiçáo de que fosse eliminada a tirania dos discursos englobantes com suas hierarquias e com os privilégios da vanguarda teórica. Chamamos provisoriamente genealogia o acoplamento do conhecimento com as memórias locais, que permite a constituição de um saber histórico das lutas e a utilização deste saber nas táticas atuais (...) as genealogias não são portanto retornos positivistas a uma forma de ciência mais atenta ou mais exata, mas anticiências (...) são os efeitos de poder próprios a um discurso considerado científico, que a genealogia deve combater" (Foucault, 1979, p. 171).

A questão não é formular a pergunta - o que é o poder? Pois se assim o fizéssemos, encontraríamos duas respostas - a da teoria jurídica clássica e a "concepção marxista geral do poder". A primeira responderia que "o poder é considerado um direito de que se seria possuidor como de um bem e que se poderia, por conseguinte, transferir ou alienar, total ou parciaimente, por um ato jurídico ou um ato fundador de direito, que seria da ordem da cessáo ou do contrato. O poder é o poder concreto que cada indivíduo detém e que cederia, total ou parcialmente, para constituir um poder político, uma soberania política. Neste conjunto teórico a Constituição do poder político se faz segundo o modelo de uma operação jurídica que seria da ordem de troca contratual. Por conseguinte, analogia manifesta, que percorre toda a teoria, entre o poder e os bens, o poder e a riqueza", enquanto a teoria marxista enfoca outra coisa. ou seja, a "funcionalidade econôrnica do poder". "Funcionalidade econômica no sentido em que o poder teria essencialmente como papel manter relaçóes de pro. dução e reproduzir uma dominação de classe que o desenvolvimento e uma modalidade própria da apropriação das forças produtivas tornaram possível" (Foucault, 1979 , p. 174-5); essa visão marxista deságua fatalmente na assertiva de que "o poder é essencialmente repressivo. $O$ poder é o que reprime a natureza, os indivíduos, os instintos, uma classe" (Foucault, 1979, p. 175).

Diferentemente dessas duas correntes, Foucault afirma que o importante não é definir ou conceituar o poder, pois, desta forma, estaríamos equivocados na afirmativa de que o poder é isto ou aquilo. $O$ poder é algo abstrato. Existem, isto sim, relações de poder e, portanto, devemos centrar nossos esforços para a análise de seus mecanismos. E esse mecanismo do poder não é do "tipo repressivo", mas "é guerra, guerra prolongada por outros meios" (Foucault, 1979, p. 176).

Em outras palavras, "fazer sobressair o fato da dominação no seu íntimo e em sua brutalidade e â partir daí mostrar não só como o direito é, de modo geral, o instrumento dessa dominação - o que é consenso - mas também como, até que ponto e sob que forma o direito (e quando digo direito nao penso simplesmente na lei, mas no conjunio de aparelhos, instituiçôes e regulamentos que aplicam o direito) póe em prática, veicula relações que não são relaçбes de soberania e sim de dominação. Por dominação eu não entendo o fato de uma dominação global de um sobre os outros, ou de um grupo sobre outro, mas as múltiplas formas de dominação que podem se exercer na sociedade. Portanto, não o rei em sua posiçáo central, mas os súditos em suas relaçбos re- 
cíprocas: não a soberania em seu edifício único, mas as múltiplas sujeiçóes que existem e funcionam no interior do corpo social" (Foucault, 1979, p. 181; grifo nosso).

E necessário explicar mais; detalhar, destrinchar o conceito de poder enquanto relação; caminhar no sentido de desvendar a prática das relaçóes de poder no interior das organizaçōes; mostrar quais essas "múltiplas sujeições" que tornam inócua, vazia, a retórica oposição dominante/dominado.

Deve-se compreender "o poder, primeiro, como a multiplicidade de correlaçoes de força imanentes ao domínio onde se exercem e constitutivas de sua organização; o jogo que, através de lutas e afrontamentos incessantes as transforma, reforça, inverte; os apoios que tais correlaçбes de força encontram umas nas outras, formando cadeias ou sistemas ou, ao contrário, as defasagens e contradiçóes que as isolam entre si; enfim, as estratégias em que se originam e cujo esboço geral ou cristalização institucional toma corpo nos aparelhos estatais, na formulação da lei, nas hegemonias sociais" (Foucalt, 1977, p. 88.9)

O poder náo é privilégio de uma classe, grupo ou in. divíduo; "o poder está em toda parte; náo porque englobe tudo e sim porque provém de todos os lugares. E o poder, no que tem de permanente, de repetitivo, de inerte, de auto-reprodutor, é apenas efeito de conjunto, esboçado a partir de todas essas mobilidades, encadeamento que se apóia em cada uma delas e, em troca, procura fixá-las. Sem dúvida, devemos ser nominalistas: o poder não é uma instituiçấo nem uma estrutura: é o nome dado à situação estratégica complexa numa sociedade determinada" (Foucault, 1977, p. 89).

\section{Alguns esclarecimentos adicionais:}

- "O poder não é algo que se adquira, arrebate ou compartilhe, algo que se guarde ou deixe escapar; $o$ poder se exerce a partir de inúmeros pontos e em meio a relaçoes desiguais e móveis;

- que as relaçōes de poder não se encontram em posiçoes de exterioridade com respeito a outros tipos de relaçớes, mas lhes săo imanentes;

- que o poder vem de baixo, isto é, não há, no princípio das relações de poder, e como matriz geral, uma oposição binária e global entre os dominadores e os dominados, dualidade que repercuta de alto a baixo e sobre grupos cada vez mais restritos até as profundezas do corpo social;

- que as relações de poder são, ao mesmo tempo, intencionais e não subjetivas (. . .) Não há poder que se exerça sem uma série de miras e objetivos;

- que la onde há poder há resistência e, no entanto (ou melhor, por isso mesmo), esta nunca se encontra em posição de exterioridade em relação ao poder (...) Elas (as correlaçóes de poder) náo podem existir senão em função de uma multiplicidade de pontos de resisténcia que representam, nas relaçóes de poder, o papel de adversário, de alvo, de apoio (. . .) Esses póntos de resis- tência estão presentes em toda a rede de poder. As resistências (...) são o outro termo nas relaçóes de poder; inscrevem-se nestas relaçóes como o interlocutor irredutível (...) Da mesma forma que a rede das relaçoses de poder acaba formando um tecido espesso que atravessa os aparelhos e as instituiçø̃es, šem se localizar exatamente neles, também a pulverizaçáo dos pontos de resistência atravessa as estratificaçós sociais e as unidades individuais" (Foucault, 1977, p. 89-92; grifo nosso).

\subsection{Regras e precauçōes metodológicas}

1. Regra de imanência. Localizar qual ou quais exigências do poder - econômicas ou ideológicas - "fizeram pesar mecanismos de proibiçăo", de ordem geral, no interior das organizaçб́es. Exemplo: as disciplinas enquanto tecnologias organizacionais.

2. Regra das variações continuas. "Não procurar quem tem o poder" (na grande empresa) "nem quem tem o direito de saber, ou é mantido à força na ignorância"; exemplo: o poder está nas máos de quem decide e, portanto, o poder é exercido pela alta administração; ou, de outro modo, o operário está privado do saber legitimado pela hierarquia social e é, portanto, ignorante; a alternativa é outra: "buscar o esquema das modificaçóes que as correlaçóes de força implicam através de seu próprio jogo. As 'distribuiçóes de poder' e as 'apropriaçōes de saber' não representam mais do que cortes instantâneos em processos, seja de inversáo da relação, seja de aumento simultâneo dos dois termos. As relaçóes de poder-saber não são formas dadas de repartiçâo, são matrizes de transformaçőes" (Foucault, 1977, p. 94).

3. Regra do duplo condicionamento. "Nenhum 'foco central', nenhum 'esquema de transformação' poderia funcionar se, através de uma série de encadeamentos sucessivos, náo se inserisse, no final das contas, em uma estratégia global. E, inversamente, nenhuma estratégia poderia proporcionar efeitos globais a náo ser apoiada em relaçōes precisas e tênues que lhe servissem, não de aplicação e conseqüência, mas de suporte e ponto de fixação (. . .) Deve-se pensar em duplo condicionamento, de uma estratégia, através de uma especificidade das táticas possíveis $\mathrm{e}$, das táticas, pelo invólucro estratégico que as faz funcionar" (Foucault, 1977, p. 95). Exemplo:a história do desenvlvimeto das "tecnologias organizacionais" desde o taylorismo até os modelos participativos de gestáo - e o contra-ataque do movimento operário. ${ }^{5}$

4. Regra da polivalência tática dos discursos. "Não se deve imaginar um mundo do discurso dividido entre o discurso admitido e o discurso excluído, ou entre o discurso dominante e o discurso dominado; mas, ao contrário, como uma multiplicidade de elementos discursivos que podem entrar em estratégias diferentes (. . .) Os discursos, como os silêncios, nem são submetidos de uma vez por todas ao poder, nem opostos a ele. É preciso admitir um jogo complexo e instável em que o discurso pode ser, ao mesmo tempo, instrumento e efeito de poder, e também obstáculo, escora, ponto de resistência e ponto de partida de uma estratégia oposta. $O$ discurso veicula e produz poder; reforça-o mas também o mina, expõe, debilita e permite barrá-lo" (Foucault, 1977, p. 95-6). 
Exemplo: o discurso do poder médico psiquiátrico e a sua reação no movimento da antipsiquiatria; o sindicato corporativista, criado no Brasil no início dos anos 40 , e a sua conseqüente reação no "novo sindicalismo" após $1977 .^{6}$

Em síntese, essas quatro regras orientam-nos "para uma concepção de poder que substitua o privilégio da lei pelo ponto de vista do objetivo, o privilégio da interdição pelo ponto de vista da efícácia tática, o privilégio da soberania pela análise de um campo múltiplo e móvel de correlações de força, onde se produzem efeitos glo. bais, mas nunca totalmente estáveis, de dominação. 0 mođelo estratégico, ao invés do modelo de direito. E isso, não por escolha especulativa ou preferência teórica; mas porque é efetivamente um dos traços fundamentais das sociedades ocidentais o fato de as correlaçбes de for. ça, que por muito tempo tinham encontrado sua principal forma de expressão na guerra, terem-se investido, pouco a pouco, na ordem do poder político" (Foucault, 1977, p. 97).

As cinco precauçðes metodológicas esboçadas por Foucault constituem questoes important íssimas de reflexão e, principalmente, de ação teórica no curso de uma investigaçăo empírica.

Primeira - "Não se trata de analisar as formas regulamentares e legítimas do poder em seu centro, no que possam ser seus mecanismos gerais e seus efeitos constantes. Trata-se, ao contrário, de captar o poder em suas extremidades, em suas últimas ramificaçóes, lá onde ele se torna capilar; captar o poder nas suas formas e instituiçôes mais regionais e locais, principalmente no ponto em que, ultrapassando as regras de direito que ogranizam e delimitam, ele se prolonga, penetra em instituicoes, corporifica-se em técnicass e se mune de instrumentos de intervençáo material, eventualmente violento (...) Em outras palavras, captar o poder na extremidade cada vez menos jurídica de seu exercício" (Foucault, 1979, p. 182 ; grifo nosso).

Exemplo: estudar uma determinada organização, uma fábrica, seus mecaismos de direçăo e controle, poder e manipulaçáo, enfim suas técnicas de "integraçăo."

Segunda - "Não formular a pergunta sem resposta: 'quem tem o poder e o que pretende, ou o que procura aquele que tem o poder?' Mas estudar o poder onde sua intenção - se é que há uma intenção - está completamente investida en práticas reais e efetivas; estudar o poder em sua face externa, onde ele se relaciona direta e imediatamente com aquilo que podemos chamar provisoriamente de seu objeto, seu alvo ou campo de aplicaçáo, onde ele se implanta e produz efeitos reais" (Foucault, 1979, p. 182):

Exemplo: não privilegiar, nas pesquisas organizacionais, a direção e suas estratégias de sobrevivência no poder de uma determinada empresa; isto é óbvio demais; ir além, descobrir como foi formado um corpo de colaboradores diretos e assessores totalmente fiéis a essa direção; descobrir as técnicas de cooptaçáo, por parte da direçấo, em relação às lideranças operárias.
Terceira - "Ter bem presente que o poder não é algo que se possa dividir entre aqueles que o possuem e o detêm exclusivamente e aqueles que não o possuem e the sáo submetidos. $O$ poder deve ser analisado como algo que circula, ou melhor, como algo que só funciona em cadeia. Nunca está localizado aqui ou ali, nunca está nas mãos de alguns, nunca é apropriado como uma riqueza ou um bem. $O$ poder funciona e se exerce em rede. Nas suas malhas os indivíduos não só circulam mas estão sempre em posiçáo de exercer este poder e de sofrer sua açáo; nunca sáo o alvo ínerte ou consentido do poder, são sempre centro de transmissáo. Em outros termos, o poder não se aplica aos indivíduos, passa por eles" (Foucault, 1979, p. 183; grifo nosso).

Exemplo: uma pesquisa empírica em uma organização deve privilegiar todos os estratos hierárquicos representativos e não, como sói acontecer, privilegiar os que "detêm o poder" ou os que "não detêm o poder"; esse ponto é básico. ${ }^{8}$

Quarta - "O importante náo é fazer uma espécie de deduçáo do poder que, partindo do centro, procuraria ver até onde se prolonga para baixo, em que medida se reproduz, até chegar aos elementos moleculares da sociedade. Deve-se, antes, fazer uma análise ascendente do poder: partir dos mecanismos infinitesimais que têm uma história, um caminho, técnicas e táticas e depois examinar como estes mecanismos de poder foram e ainda sro investidos, colonizados, utilizados, subjugados, transformados, deslocados, desdobrados etc., por mecanismos cada vez mais gerais e por formas de dominaçáo global" (Foucault, 1979, p. 184; grifo nosso).

Exemplo: investigar os modelos participativos im. plantados em uma determinada organização; examinar a história da institucionalizaçăo desse estilo gerencial; ampliar a amostra para todo um setor; fazer análises comparativas entre países do centro e da periferia, entre empresas transnacionais e empresas nacionais, entre o setor empresarial do Estado e o setor privado; investigar se essas estratégias participativas fazem parte de uma estratégia global de absorçáo de conflitos. ${ }^{9}$

Quinta - "É bem possivel que as grandes máquinas de poder tenham sido acompanhàdas de produçoes ideológicas. Houve provavelmente, por exemplo, uma ideologia da educação; uma ideologia do poder monárquicu, uma ideologia da democracia parlamentar etc.; tudo isso significa que o poder, para exercer-se nestes mecanismos sutis, é obrigado a formar, organizar e pôr em circulação um saber, ou melhor, aparelhos de saber que não são construções ideológicas (...) São instrumentos reais de formação e de açumulação do saber; métodos de observação, técnicas de registro, procedimientos de inquérito $e$ de pesquisa, aparelhos de verificaçro" (. . .) Finalmente, é "preciso estudar o poder colocando-se fora do modelo do Leviatã, fora do campo delimitado pela soberania jurf́dica e pela instituição estatal. E preciso estudá-lo a partir das técnicas e táticas da dominação" (Foucault, 1979, p. 186).

Exemplo: a importância das escolas profissionais, preparadoras de máo-de-obra para o setor produtivo: a importância, hoje em dia, da formaçáo operária e técnica no interior da indústria; enfim, a escola como instância disciplinadora da força de trabalho. ${ }^{10}$ 


\section{METODOLOGIA}

Nosso objetivo: estudar o processo de trabalho no interior da grande indústria, a partir de um quadro teóricometodológico centrado na questáo do poder e do controle e a resposta ou "reaçáo" dos que sáo instituídos pela instituiçăo-fábrica. ${ }^{11}$

Em primeiro lugar, faz-se necessário apresentarmos a nossa definição de dois conceitos-chave - processo de trabalho e instituiçáo (ou organização) - e, em seguida, apresentarmos as diretrizes básicas de nossa metodologia e suas possibilidades de teste empírico.

É importante salientar que "o processo de trabalho surge como um locus privilegiado de expressáo das contradiçōes que regem as relaçбes capitalistas de produção, dada a sua dupla natureza: de ser um processo, simultaneamente, de fabricação de mercadorias dotadas de utilidade social (valor de uso) e de produçáo de valor excedente (processo de valorização)".

"No primeiro sentido, todas as sociedades produzem através de processos de trabalho, mas a característica especifica do processo de produçáo capitalista é que nele a segunda natureza domina a primeira, isto é, o processo de fabricação de mercadorias é apenas um meio para o processo de valorização ou de criaçăo de valor excedente. A contradiça fundamental entre capital e trabalho que permeia as relaçóes sociais numa sociedade capitalista expressa-se em vários planos dessas relaçóes: na estrutura econômica, na estrutura política e no nivel das ideologias. Pode-se afirmar, porém, que a base material de última instância em que se baseia tal contradição fundamental está na dupla dominaçáo que o capital procura manter sob o trabalho: na forma da propriedade dos meios de produção e na forma do controle real sobre o processo de produção (Pereira, 1979, p. 20; grifo nosso).

Nesse sentido, iremos analisar o processo de trabatho sob a ótica do processo de acumulaçáo (produção do sobretrabalho) que envolve, necessariamente, o estudo das estratégias gerenciais de um controle real e efetivo sobre o processo de produção, visando, obviamente, a maximização da produção do valor excedente. ${ }^{12}$

Em outras palavras, isso quer dizer que "não entendemos por processo de trabalho apenas as condiços materiais ou tecnológicas em que se realiza a fabricafáo de mercadorias, mas consideramos elemento essencial a esse processo a forma social de organização do trabalho em que a produção se realiza" (Pereira, 1979, p. 21 ; grifo nosso); e, evidentemente, trazer à toma a resposta (reaçāo) dos trabalhadores, no interior das unidades produtivas, a tal tipo de estratégias patronais. ${ }^{13}$

O nosso conceito de instituiçăo (ou organização) parte do pressuposto de que ela é "um conjunto articulado de saberes (ideologias) e príticas (formas de interven f̧áo normalizadora na vida dos diferentes grupos e classes sociais). Estes conjuntos (instituiçбes) permeabilizam grande parte das atividades humanas dentro da so. ciedade, em cada bloco histórico. Esta rede de instituiçóes viabiliza a hegemonia e, portanto, a manutençáo de toda a imensa infra-estrutura que sobre ela repousa, para retormar, invertida, a imagem clássica. Neste sentido, trata-se de ver as instituiçoes como conjunto articulado, como ligação vital de saberes e práticas com efeitos fundamentalmente políticos, envolvendo uma estratégia de luta - não necessariamente aberta - entre grupos e classes sociais constitutivos destas instituiçóes e inseridos em um bloco histórico" (Luz, 1979, p. 31).

0 conceito de organizaçáo - fábrica - envolve, como diz Foucault, lucro e subpoder, ou melhor, sobrelucro e subpoder, os micropoderes que permeiam toda a instituiçáo e "a resistência e a contra-hegemonia como reverso necessário" (Luz, 1979, p. 31).

Para se entender a natureza da organização tem-se que ir além do "dito", do normalizado, enfim do sistema burocrático explícito, para fugirmos às armadilhas funcionalistas do tipo "disfunçóes da burocracia"; é necessário enxergar mais longe e ver as instituiçoes como "núcleos específicos de poder" que têm por finalidades básicas a funçâo de "formar, controlar e reprimir".

A função de controle e punição tem por objetivos principais tornar os corpos dóceis, produtivos e disciplinados (Garcia, 1982), enquanto em função de formar "a instituiçáo - escola, hospital, caserna, escritório (e empresas em geral) - não reprime, molda. Não está interessada em punir, em excluir, mas em integrar. Apenas olha com desconfiança 0 aluno insubmisso, o paciente indócil, o soldado indisciplinado, o funcionário indolente. Cada um tem potencialmente os quatro defeitos. Essas negatividades podem dar nascimento à quebra da disciplina, da ordem e da hierarquia. Apontam já para o desviante. Indócil pode ser o paciente que pergunta, o 'criador de caso'. Insubmisso o aluno questionador. Indisciplinado é o aluno que não respeita horários, lugares, regras concernindo o tempo e o espaço da escola. Tudo isto pode ser aplicado ora a um, ora a outro agente da instituiçấo" (Luz, 1979, p. 38) mas, por outro lado, conforme falávamos anteriormente, $\mathrm{o}$ instituído (operário, funcionário, aluno etc.), vislumbra formas de contra-hegemonia, de resistência, enfim de subpoderes.

Do ponto de vista metodológico, como não poderia deixar de ser, o nosso trabalho distancia-se bastante das análises funcionalistas e estruturalista (tanto do ponto de vista weberiano como do marxista), haja vista que, enquanto, na primeira, os estudos de organizaçóes têm-se "reduzido à descriça de sistemas e meios, a conjuntos de normas especializadas que remeteriam, finalmente, a Fins Ideais (Valores Sociais) cuja encarnação se faria no Estado", ou, em outras palavras, na "Ordem Social", o que resultaria, obviamente, em uma percepçáo da visáo dominante e do discurso da Ordem e do Poder, na segunda "acaba-se vendo o aspecto estrutura como reflexo da dominaçāo", ou seja, a única alternativa de mudança acabaria sendo a "desinstitucionalizaçáo radical da sociedade" (Luz, 1979, p. 25-6) - o que, diga-se de passagem, está no plano das utopias! !14

Sendo assim, a nossa metodologia (ou método), na falta de um nome mais apropriado, poderia ser caracterizada como histórico-discursiva, pois, ao mesmo tempo em que trabalhamos com o conjunto dos dados históricos relativos a uma determinada organizaçáo (e sua articulaçăo com a história política das instituiçoes), ela orienta nossa investigaça empírica para "as fissuras internas" das práticas organizacionais; para as "respostas dos que sáo instituídos por essas práticas. Tais respotas incluem todas as formas de resistências e podem variar do bloqueio à sabotagem, de oposiçăo d̀ rejeiçấo aberta das 
normas e dos discursos dominantes", ou seja, ela busca "exprimir as contradiçoes institucionais tanto a nível discurso/prática e a nível interno do discurso, como a nivel das respostas daqueles que a instituiça social tenta enquadrar" (Luz, 1979. p. 26).

Em um trabalho recente, realizado numa grande em. presa multinacional europeia (Fagès et alii, 1979), ou au. tores, de certa forma, utilizam essa mesma metodologia, apresentando-a, porém, com o nome de "um método dialético de análise de conteado", em que os pressupos. tos metodologicos básicos são:

- caráter dialético do objetivo de discurso e de análise;

- discurso 'objetivo' ou 'subjetivo';

- discurso individual, discurso coletivo;

- estatuto do tema, unidades de discurso e tratamento das conexð̋es;

- os gráficos de interpretaçðes”' (Pagès et alii, 1979 p. 208).

Esses pressupostos metodológicos irðo privilegiar um sistema de 11 variáveis, a saber: a) $a$ instância do econômico; b) o sistema técnico e científico; c) o processo decisorio; d) a ideologia; e) a política de pessoal; f) o processo de trabalho propriamente dito; g) 0 plano de carreira; h) os conflitos e rivalidades intergrupos; i) a identidade; j) a palavra e o espaço organizacional; l) a empresa versus a sociedade global (Pages et alii, 1979) ou seja, essas variáveis é que irão operacionalizar o método histórico-discursivo por nós apresentado anteriormente, bem como a forma de tratálos será a contraindução ${ }^{15}$ ou, na linguagem de Pages e colaboradores, "a dialética de dução-indução".

A título de ilustraçáo e para mostrarmos as reais possibilidades de um teste empírico do nosso quadro teórico-metodológico, comentaremos alguns dos resultados encontrados nessa grande empresa multinacional européia, localizada na França, bem como os resultados encontrados em uma pesquisa realizada em duas grandes empresas atuomobilísticas no Brasil (Sáo Bernardo do Campo, SP), utilizando, também, a estratégia metodológica histórico-discursiva (Humphrey, 1981).

Quanto à primeira pesquisa (Pagess et alii, 1979), os autores, pesquisando (através da aplicaçfo de entrevistas abertas e nấo-estruturadas aos diversos estratos hierár: quicos da empresa) o sistema de poder na organizaçăo, depararam com respostas do tipo "eu amo e eu detesto TLTX", "Eu sou explorado de uma maneira agradável" e, ao mesmo tempo, com respostas do tipo "TLTX é uma sociedade humana onde se consideram os indivíduos", o que vem confirmar a adoção do pressuposto metodológico de se analisarem as características dialéticas do objeto de discurso e de análise, ou seja, temos que estar bastante atentos às caracteristicas contraditórias do entrevistado vis-à-vis às contradiçóes da sociedade e não, como falávamos na introdução deste trabalho, ficarmos apegados a conceitos desgastados e estáticos como a "dominaçóo em geral" e seu corolário dominante/ dominado.

E necessário ir mais além e detectar que, no caso da TLTX, políticas semelhantes da empresa provocaram reaçoes positivas e negativas; a política de pessoa, por exemplo, promoveu vantagens para um segmento ou grupo e desvantagens para outro, a ideologia, os grandes princípios foram criticados por uns e aprovados por outros etc. (Pages et alii, 1979).

A pesquisa realizada no setor automobilístico brasileiro confirma essas "contradiçoes", dadas, principalmente, as diferenças significativas no interior das indústrias pesquisadas entre o operário qualificado por um lado e, por outro, o operário semiqualificado e nao-qualificado. Em linhas gerais, quanto ds políticas de pessoal das empresas pesquisadas, 0 autor conclui que: "a) quanto mais o trabalho a ser executado for suscetivel de especificaçăo, menos incentivos teráo que ser oferecidos aos trabalhadores; b) quanto maior for a qualificaçáo reque. rida, maior será a necessidade de incentivos e menor será a necessidade de controle direto do ritmo de trabalho. Isso é bastante visível na ferramentaria, onde as tarefas sáo flexíveis e os ritmos de trabalho náo controlados estritamente ; c) quanto maior for a responsabilidade dos trabalhadores, mais cuidado deve tomar a administraçáo, de modo a assegurar a realizaçáo adequada das tarefas. Por exemplo, em certos setores da indústria química, são pagos altos saldrios e despendidos grandes esforços para dar aos trabalhadores a consciência de sua responsabilidade, em virtude da importância da supervisto constante de processos contínuos, perigosos e caros; d) quanto maior for a escassez de máo-de-obra, maior será a necessidade de utilizar incentivos, em lugar de controle direto dos trabalhadores. Isso fica bem claro no caso dos operários qualificados no Brasil. Os administradores admitem que eles sto mais difíceis de controlar que os semiqualificados ou náo-qualificados; e) quanto maior for a força das organizaçoes dos trabalhadores e maior a liberdade política de tais organizaçoes, maior será a necessidade de incentivos, porque o poder de controle direto por parte da administraçáo será reduzido" (Humphrey, 1981, p. 45; grifo nosso). Esses indicadores, de per si já definem qữo heterogêneas sáo as políticas da grande indústria no Brasil, independentemente das tecnologias adotadas, pois, pelas razoes aqui esboçadas, pode-se concluir que existem "grandes diferenças, mesmo no interior do chamado 'setor moderno' da indústria e não há determinaçato das políticas de emprego pelo tipo de tecnologia empregado" (Humphrey, 1981, p. 45).

Em relaçáo à nossa pesquisa propriamente dita, propomos, enquanto estratégia metodológica para nossa investigaçăo, as seguintes variáveis:

a) sistema disciplinar da empresa;

b) processo de trabalho;

c) política de pessoal;

d) plano de carreira (cargos e salários);

e) técnicas de integraçăo (cooptaçâ);

f) conflitos (interpessoal e intergrupal);

g) breve história da organização e evolução do movimento sindical.

Por se tratar de uma pesquisa em que as análises serão, fundamentalmente, de natureza qualitativa, optamos pelo método do estudo de caso nas seguintes indústrias: Usiminas, Belgo-Mineira, Mannesman e Acesita basicamente pelo porte e a dimensto que elas representam no subsetor siderúrgico da metalurgia mineira. 
A operacionalização das variáveis far-se-á através de três instrumentos metodológicos, a saber:

1. Uso de fontes secundárias para:

a) levantamento e reconstruçáo histórica da evoluçáo técnica e organizacional das indústrias a serem pesquisa. das;

b) levantamento e reconstrução histórica do movimento sindical relacionado com os casos estudados.

2. Observação direta näo-participante da organização do trabalho e da técnica adotada nas unidades de produçáo. Os aspectos relevantes nesta observaçáo serão:

a) observação da localizaçáo espacial das empresas e do conjunto habitacional dos operários;

b) observação da organização do processo produtivo global - etapas do processo;

c) observaçáo dos postos de trabalho - trabalho individual e/ou em grupo, uso de máquinas e/ou ferramentas; d) situação dos operários em relação ao ambiente coletivo de trabalho densidade de trabalhadores, temperatura, ruído, vibração, atmosfera e periculosidade;

e) situação dos operários em relação à carga física do trabalho - postura e esforço físico;

f) situação dos operários em relação à carga mental do trabalho - atividade sensorial dominante (destreza, tensão visual ou auditiva);

g) situação dos operários em relaçáo ao tempo de trabalho - ritmo, duração das pausas, tempo não-produtivo e cadência (dependente da máquina ou do indivíduo).

\section{Entrevistas abertas e parcialmente gravadas com:}

a) dirigentes;

b) operários - de acordo com a classificaçáo hierárquica estabelecida internamente pela empresa ;

c) dirigentes sindicais.

Em linhas gerais, portanto, acreditamos que a metodologia histórico-discursiva, ao privilegiar, principalmente, $o$ discurso individual e coletivo, o discurso objetivo e subjetivo, as características "dialéticas" do objeto do discurso e do objeto de análise e centrando o seu inquérito em entrevistas não-estruturadas e informais, num momento com os funcionários do capital (elites organizacionais) e, num outro momento, junto aos trabalhadores diretamente ligados à produção - operários, contramestres e supervisores - estaremos mostrando os subpoderes, os micropoderes que atuam e dão significado, quer ao "procésso de valorização" e ao "processo de acumulação" de capital, quer aos movimentos de resistência, de combate, de luta, de uma estratégia de contra-hegemonia levado a cabo pelos trabalhadores. ${ }^{17}$

\section{CONCLUSOESS}

Em primeiro lugar: entender as organizaçoes como locus de resposta às contradiçoes, onde as estratégias gerenciais buscam o efeito e $O$ alcance da integraçáo; entender como um sistema dinâmico onde, ao mesmo tempo, se "ama" e se "odeia", se realiza e (ou) se é excluído, onde se tem "prazer" e "angústia"; enfim, compreender as organizaçōes, não como "um conjunto de dados, objetjvos, capital, dificuldades, mão-de-obra, procedimentos etc., onde se limita a constatar a existência de uma perspectiva possitivista, bem como em estudar as articulações sistêmicas (...) A organizaçáo é, isto sim, um conjunto dinâmico de respostas às contradiçóes (...) Não se pode compreender como nasce e se transforma uma organizaçăo sem fazer referência ao seu fundo negativo, não numa perspectiva positivista, mas dialética. A organização é, nada mais nada menos, do que uma vasta 'zona intermediária' que se interpoe às contradiçóes de classe, evita ou atenua os conflitos, os absorve e os integra dentro de um sistema social unificado, mas é constantemente sustentada e produzida por eles" (Pages et alii, 1979, p. 30-1; grifo nosso).

Em segundo lugar: entender o poder na sua forma micro, não atrelado ao poder de Estado e seus aparelhos, mas como uma multiplicidade de correlaçoes de força, como luta e combate, como um circuito em rede, de uma forma ascendente; enfim, como algo que permeia todo o tecido social, nâo como algo repressivo, mas, pelo contrário, localizando seus efeitos, suas estratégias etc.

Finalmente, em terceiro lugar: abandonar a dicotomia tradicional/moderno em relação ao setor industrial, pois não acreditamos, juntamente com Humphrey (1981), no determinismo da tecnologia, ou seja, mudanças nos padróes tecnológicos não promoveráo mudanças significativas nas relaçōes de trabalho.

A estratégia não é local, regional ou nacional; a estratégia é universal, independentemente de tecnologias mais ou menos sofisticadas. 0 processo de trabalho não é diferente na indústria automobilística de Detroit, Milão ou São Paulo. Como diz Foucault, onde houver lucro, haverá, necessariamente, subpoderes. Essa é a estratégia global.

Anexo 1

Roteiro orientador das entrevistas com os dirigentes das empresas a serem pesquisadas: gerentes - administrativo, recursos humanos e de produçăo.

1. Dados gerais - GA

1.1 Capital social

1.2 Data da fundaçáo

1.3 Estrutura de propriedade: capital nacional - estatal capital internacional privado

2. Estrutura organizacional - GA

2.1 Organograma

2.2 Existe uma política de estilos gerenciais?

2.3 Breve história da organização: principais transformaçoes.

3. Controle da produçáo e da qualidade - GP

3.1 Formas e métodos de controle: ECG, GSA, CCQ, taylorismo-fordismo

3.2 sistema de prémios 
4. Política de cargos e salários - GRH

4.1 Classificaçăo de pessoal

4.2 Estrutura de salários: hora, mensal (percentagem da FT empregada)

4.3 Subcontratação de mão-de-obra

4.4 Evoluçáo do mercado de trabalho

5. Política de recursos humanos - GRH

5.1 Recrutamento e seleçáo

5.2 Treinamento

5.3 Indices de absente ismo e turn-over (detectar as principais causas - por exemplo: doença)

5.4 Política de bem-estar social

5.5 Sistema de promoçáo interna

6. Outros problemas na gerência de máo-de-obra - GRH 6.1 A aplicação de penas disciplinares é muito freqüente? Se sim, quais os principais motivos?

6.2 Greves

6.3 Relacionamento com os sindicatos

6.4 Indices de segurança no trabalho

6.5 Política da empresa em relação à insalubridade e ao ambiente físico do trabalho

Anexo 2

Roteiro das entrevistas com os operários

1. Dados gerais

1.1 Idade

1.2 Sexo

1.3 Estado civil

1.4 Local de habitação (nome do bairro - operário ou กล์o)

2. Características do posto de trabalho (saber o eixo estratégico)

2.1 Nome do posto

2.2 Qualificação profissional

2.3 Salário

2.4 Formas de aprendizado das tarefas

2.5 Causas de acidentes de trabalho

2.6 Qual o principal problema de seu trabalho?

$2.7 \mathrm{Em}$ que momento do trabalho voce recorre ao mestre ou contramestre?

2.8 Vinculo empregatício: contratação ou subcontratação

3. Cadência de trabalho (explorar o máximo possível todos os comportamentos que indicam formas de resistência)

3.1 Você trabalha sempre no mesmo ritmo?

3.2 Existem trabalhadores que trabalham mais rápido que os outros? Por quê?

3.3 Quem decide quanto você vai produzir por dia?

3.4 Existem instruçסes de segurança? Você as respeita ou não? Por quê?

3.50 tempo que você tem para realizar sua tarefa é estabelecido pela chefia?

4. Qualidade do trabalho (ver percentagem de erros, causas, tipos etc.)

4.1 Como é controlada a qualidade de seu trabalho?
4.2 0 que o supervisor ou mestre faz quando a qualidade não obedece aos padroes?

5. Horário de trabalho

5.1 Como é estabelecida a jornada de trabalho? (turno: fixo ou variável)

5.2 A empresa adota o sistema de horas extras?

6. Estabilidade no emprego

6.1 Há quanto tempo você está na empresa?

$6.2 \mathrm{E}$ na anterior?

6.3 Foi demitido ou pediu demissáo da empresa anterior?

6.4 E fácil trocar de emprego dentro da sua especialidade?

7. Sindicalizaçáo

7.1 Para que serve um sindicato?

7.20 que você acha do seu sindicato?

7.3 Você participou das últimas greves? Por quê?

8. Percepçáo do operário sobre as novas formas de organizaço do trabalho

8.1 Qual a sua reação frente aos GSA ou CCQ?

8.2 Existe rotatividade de funçoses?

8.3 A hierarquia é muito rígida? (ir ao banheiro)

8.40 que você acha do sistema de promoçáo?

8.50 que você acha do sistema de controle?

8.6 Você participa de alguma decisáo? (operacional)

8.70 que você acha dos benefícios indiretos que a empresa oferece? Todos os operários podem usufruir desses benefícios?

8.8 Quais as formas espontâneas de resistência às metas fixadas pela chefia?

8.8.1 Operação zelo

8.8.2 Operação soluço

8.8.3 Operação acidente

8.8.4 Ludismo

8.8.5 Operação gato selvagem

8.8.6 Operaçáo mosquitinho

8.8.7 Operaçáo espionagem

8.8.8 Comunicaçáo horizontal

8.8.9 Existem outras de que você já participou?

9. Você teria alguma coisa a mais a dizer sobre o seu dia de trabalho?

Anexo 3

Roteiro orientador para a entrevista com os dirigentes sindicais

1. Dados gerais

1.1 Nome do sindicato

1.2 Data da fundaçáo

1.3 Número de sindicalizados

2. Estrutura organizacional

2.1 Número de funcionários

2.2 Estrutura propriamente dita - departamento, divisores etc.

2.3 Pessoal especializado - médico, dentista, advogado etc.

2.4 Pessoal administrativo 
2.5 A diretoria já fez cursos? Se sim, quais? No Brasil? No exterior?

2.6 Há quantos mandatos o(s) diretor(es) estão exercendo o cargo?

\section{Reconstituição histórica do movimento sindical}

\section{Atuação do sindicato}

4.1 Em relaçáo às políticas govemamentais

4.2 Em relaçáo às empresas

4.2.1 Qual a percepçáo do sindicato em relação ao estilo gerencial?

4.2.2 Qual a estratégia do sindicato em relaçáo a essas novas formas de gestão?

${ }^{1}$ A questão do poder, na obra de Marx, está superficialmente analisada em apenas dois textos, que tratam da Comuna de Paris e do Bonapartismo, mas que dão bem a dimensão do poder entendido como poder de Estado e seus aparelhos. Consultar Marx, K. Les luttes de classes en France. Paris, Sociales, 1974; e 018 Brumário de Luís Bonaparte. In: Os pensadores. São Paulo, Abril, 1974. A problemática de uma teoria política em Marx possui um amplo espectro, bem como uma extensa bibliografia que, por motivos óbvios, náo cabe aqui comentar; mas uma síntese de toda a discussão, de uma forma brilhante, pode ser encontrada em: Bobbio, N. et alii. Marxismo e Estado. Rio de Janeiro, Graal, 1979.

Sobre o conceito de poder, sob a ótica golpista do leninismo-stalinismo, bem como uma extensa crítica a essa abordagem, consultar: Garcia, Fernando C. Partidos politicos e teoria da organizaçẽo. São Paulo, Cortez e Moraes, 1979.

Para uma análise mais recente dos desdobramentos do marxismo-teninismo-stalinismo, na Uniāo Soviética, uma crítica radical se encontra em: Levy, B.H. La barbarie d visage humain. Paris, Grasset, 1977; Benoist, J.M. Marx est mort. Paris, Gallimard, 1979; e, principalmente, em: Glucksman, A. La cuisinière et le mangeur d'hommes; essai sur L'État, le marxisme, les camps de concentration, Paris, Seuil, 1975.

Para uma compreensão da análise do poder e autoridade na visão weberiana, consultar; Weber, Max Economia y Sociedad. Mexico, Fondo de Cultura Económica, 1969. Ver, em especial, capítulos 8 e 9, p. 661-1.046.

Um resumo enriquecedor da obra de Weber, sob a perspectiva do poder e da autoridade, está em: Martin, Roderick. Sociologia do poder. Rio de Janeiro, Zahar, 1978.

${ }^{2}$ Zald, Mayer N., ed. Power in organizations. Nashville, Vanderbilt University Press, 1970; Blau, P. \& Schoenherr, A.R. The structure of organization. New York, Basic, 1971; Weick, K.E. The social psychology of organizing. Massachusetts, Addison Wesley, 1969.

Uma resenha comentada das várias tendências funcionalistas e empiricistas, ao tratar o eonceito de poder em organizaçes formais, encontra-se em: Bacharach, S.P. Morphologie et processus: une critique de la recherche organisationnelle contemporajne. Sociologie du Travall, Paris, 20(20):153-73, avr./juin 1978.

${ }^{3}$ Mills, C.W. A imaginação sociológica. Rio de Janeiro, Zahar, 1969. Mills, ironizando a obra básica do funcionalismo - The social system, de Talcott Parsons - conclui: "Nesses termos, a idéia de conflito não pode ser formulada efetivamente. Os antagonismo estruturais, as revoltas em grande escala, as revoluçôes - não podem ser imaginados. Na realidade, supōe-se que o 'sistema', uma vez estabelecido, não só é estável como intrinsecamen te harmonioso; nessa linguagem, as perturbaçoes têm de ser 'introduzidas no sistema'. A idéia da ordem normativa assim apresentada nos leva a supor ama espécie de harmonia de interesses como característica natural de qualquer sociedade; tal como surge aqui, essa idéia é uma âncora metafísica, tal como o foi a idéia semelhante entre os filósofos da ordem natural, no século XVIII" (p. 51).

4 "Mas os problemas reaimente começam quando se deseja saber 0 que significa 'estar por baixo' no Brasil. Será que aqui a sociedade se divide claramente em dominantes e dominados, tendo o corte conceitual e político um correspondente econômico, residencial e étcnico, nítido?

Será que, entre nós, dominantes e dominados se encarnam em grupos homogêneos e visíveis material e politicamente? Ou será que as categorias 'dominante e dominado' formam o que Evans-Pritchard chamou de 'oposição segmentar'? De fato, se no caso da sociedade brasileira pode-se pensar a oposição dominante/dominado como um par segmentário, então teremos possibilidades básicas de relativização, já que a segmentaçäo remete a grandes inconsistências entre os grupos e suas relações com os recursos de poder que controlam. No Brasil, entâo, a dicotomia 'dominante/dominado' tenderia sempre a se repetir no interior de cada termo, sendo sempre relativa a quem o aplica, como está sendo aplicada e para que se aplica (...) Se estamos interessados no mundo real, querendo descobrir a sua dinâmica concreta, então verificamos logo que 'dominante' e 'dominado' sâo dois termos complexos já que entre os 'dominantes' existem 'dominados' e 'dominantes', o mesmo ocorrendo com os 'dominados' (Da Matta et alii, 1982, p. 18-9; grifo nosso).

E, mais adiante, continua o brilhante antropólogo: "Pois bem, nesta perspectiva nāo seria justo dizer que temos 'dominantes' e 'dominados' em todas as áreas da sociedade? Na familia e na universidade, nos partidos políticos e na fábrica, no sindicato e na igreja, entre empresários, financistas e fazendeiros? $\mathrm{E}$ até mesmo no interior do próprio grupo que detém o poder político e o monopólio da força? Ou seja: onde quer que exista uma organização, essa dicotomia tende a surgir como modo de compensaçāo social, e uma gradaçāo é imediatamente estabelecida entre quem está por baixo e quem está por cima (...) Assim, o procedimento de um subalterno ou inferior é idêntico ao do superior, só que o último pode usar um sonoro 'você sabe com quem está falando?', e o primeiro tem que apelar para a violência e para a força bruta. A idéia é a mesma, mas os meios são diferentes" (Da Matta et alii, 1982, p. 20-41).

5 "A introdução em grande escala da maquinaria, na primeira metade do século XIX, é percebida pelos operários como um ataque direto ao qual reagem quebrando as máquinas. 'São derrotados, mas imprimem uma forma de luta nas fábricas: a resistência à produção. $\mathrm{O}$ capitalismo responde generalizando o salário por peça e por rendimento. Ambos são novamente contestados através da constestação das normas. $O$ taylorismo é a resposta capitilista: as normas serāo de terminadas cientificamente e 'objetivamente'. A resistência operária consiste em demonstrar dia a dia que essa 'cientificidade' é uma piada, pois, entre outras coisas, é possivel impedi-la de funcionar justamente porque os trabalhadores conhecem as peças e as máquinas, seus problemas e sua eficácia muito melhor do que os técnicos 'dos métodos'. A resposta capitalista nấo se faz esperar: a psicologia e a sociologia industriais, o malsinado DRH, devem 'integrar' os operários à empresa. Os operários burlam o 'saber' dos cientistas sociais. $O$ capitalismo dos países avançados encontra a resposta: superexploração da mais-valia na 'periferia' e concessão de salários mais altos, menores jornadas de trabalho e, em alguns casos, co-gestão para os operários do 'centro' (Chauí, 1981, p. 140).

$\mathrm{E}$, sobre a dignidade do trabalhador, a filósofa continua sua crítica avassaladora, perguntando "quais os conteúdos dessa dignidade? Inicialmente, ela é a dignidade do trabalhador enquanto ser. humano (que por isso exige salários, condiçōes de emprego e de trabalho dignos de uma existência humana e não para uma mera sobrevivência biológica). Ela é, também, a dignidade daqueles que se sabem produtores da riqueza apropriada por $u m$ punhado de exploradores organizados (e por isso a greve surge como demonstração desse conhecimento). Ela é, ainda, a dignidade daquele que conhece seu ofício e contra quem o patronato lançou o poder dos 'métodos' e do DRH (por isso, a exigência de 
participação na produção aparece como correção, a curto prazo, da alienação em que o trabalho se encontra submetido). Mas ela é, sobretudo, o reconhecimento do direito de agir e pensar sem tutela, seja esta qual for e venha de onde vier, pois os trabalhadores nāo sāo apenas 'māos', porém cabeças pensantes" (Chauí, 1981 , p. 209).

Sobre a problemática da democracia participativa no âmbito das fábricas e sua articulação com a teoria política clássica, consultar, para maior aprofundamento: Macpherson, C.B. A de: mocracia liberal; origens e evolução, Rio de Janeiro, Zahar, 1978.

6 "No cerne da antipsiquiatria existe a luta com, dentro e contra a instituição" (Foucault, 1979, p. 126). Sobre o movimento da antipsiquiatria consultar, entre outros: Szasz, T.S. A ideologia da doença mental. Rio de Janeiro, Zahar, 1977; Laing, R.D.A polf. tica da famitia. Lisboa, Portugália, 1973; Cooper, D. Psiquiatria e antipsiquiatria. São Paulo, Perspectiva, 1978.

Sobre a questão do "novo sindicalismo" como reação (resposta) ao sindicato corporativista, consultar : Moisés, J.A. A estratégia do novo sindicalismo. Revista de Cultura e Poltitica. Sāo Paulo, 2(5/6):59-79, abr./set. 1981; Frederico, C. A vanguar. da operária. São Paulo, Símbolo, 1980; Tavarès, M.H. Tendências recentes da negociação coletiva no Brasil. Dados, Rio de Janeiro, 24(2):161-90, maio/set. 1981; Rodrigues, Leốncio $M$. et alii. Trabalho e cultura no Brasil. Brasilia, CNPq/Anpocs, 1981 ; Lamounier, B. \& Souza, A. Governo e sindicatos no Brasil: a perspectiva dos anos 80. Dados, Rio de Janeiro, 24(2):139-60, maio/set. 1981 ; Sader, E. \& Sandroni, P. Lutas operárias e táticas da Burguesia. Cadernos PUC de Economia, São Paulo, 3(7):13-43, maio 1981 .

Numa passagem das mais interessantes do trabalho de Sader \& Sandroni, os autores, dissertando sobre a greve de 1978 , reproduzem uma entrevista de um operário em que ele afirma que "foi uma decisão espontânea do pessoal do turno diurno da seção de ferramentas. Os trabalhadores do turno da noite estavam saindo, quando os do turno seguinte entraram, mas não ligaram as máquinas (...) Entre as 7 e as $\mathbf{8}$ da manhã ficamos de braços cruzados diante das máquinas sem fazer nada. Às 8 , chegou o gerente-geral. Ele certificou-se de que os cartōes estavam marcados, de que havia luz, mas de que ninguém estava trabalhando. Aquilo lhe pareceu estranho, mas náo acreditou que se tratava de uma greve. Creio que ele não entendeu o que estava acontecendo, pois jamais poderia imaginar que ocorreria uma greve. Foi uma surpresal" (p. 27).

${ }^{7} \mathrm{O}$ melhor estudo que conhecemos, realizado no Brasil, é o de Humphrey, J. Controle capitalista e luta operúria na indústria cutomobilistica. Petropólis, Vozes, 1982.

8 "Existe atualmente um grande desconhecido: quem exerce o poder? Onde o exerce? Atualmente se sabe, mais ou menos, quem explora, para onde vai o lucro, por que máos ele pasea e onde ele se reinveste, mas o poder (... .) Sabe-se muito bem que não são os governantes que o detêm. Mas a noçâo de 'classe dirigente' nem é muito clara nem muito elaborada. 'Dominar', 'dirigir', 'governar', 'grupo no poder', 'aparelho de Estado' etc., é todo um conjunto de noções que exige análise. Além disso, seria necessário saber até onde se exerce o poder, através de que revezamentos e até que instâncias, freqüentemente ínfimas, de controle, de vigilância, de proibiçōes, de coerçōes. Onde há poder, ele se exerce. Ninguém é, propriamente falando, seu titular; e, no entanto, ele sempre se exerce em determinada direḉ̧, com uns de um lado e outros de outro; não se sabe ao certo quem o detém; mas se sabe quem não o possui"' (Foucault, 1979, p. 75).

${ }^{9}$ Nos EUA existem, hoje, mais de 2 mil grandes e médias empresas em que as técnicas dos CCQ (Círculos de Controle de Qualidade) foram implantadas; sabemos, também, que essa técnica "participativa" foi desenvolvida no início dos anos 60 no Japão, onde existe mais de 1 milhão de CCQ. Para maiores detalhes, consultar: Ouchi, William. Teoria $Z_{\text {; }}$ como as empresas podem enfrentar o desafio japonês. São Paulo, Fundo Educativo Brasileiro, 1982.

No Brasil, como era de se esperar, a moda está em plena ascensão, como mostra uma extensa reportagem publicada na revista Exame (de 25 de agosto de 1982); só para se ter uma idéia, existem 400 empresas que já implantaram definitivamente os CCQ, dentre elas empresas do porte de Ford, Metal Leve, Rhodia e Souza Cruz.

10 Sobre a importância da escola na preparação de uma mão de-obra dócil e disciplinada, consultar: Bourdieu, P. \& Passe ron, J.C. $A$ reproduçäo. Rio de Janeiro, Francisco Alves, 1975; Durand, J.C., org. Educaçāo e hegemonia de classe. Rio de Janeiro, Zahar, 1979; Boudon, R. Efeitos perversos e ondem social. Rio de Janeiro, Zahar, 1979; Rossi, W.G. Capitalismo e educaf̧ão. São Paulo, Cortez e Moraes, 1978; Tragtemberg, M. Sobre educaçđ̃o, politica e sindícalismo. São Paulo, Cortez, 1982; Arroyo, M.G. Administração da educação, poder e participação. Educaf̧đo e Soctedade, São Paulo, 2(1): 36-46, jan_/abr. 1979.

11 Esse trabalho faz parte de uma pesquisa empírica a ser realizada no setor siderúrgico de Minas Gerais, tendo como amostra as quatro principais usinas em operaçāo, sendo duas do setor privado (ambas multinacionais) e as outras duas do setor estatal.

12 Didaticamente, podemos dizer que o processo de trabalho "pode ser definido como um processo pelo qual matérias-primas, ou outros insumos, sáo transformados em produtos com valor de uso. Esse processo é uma combinação de três elementos: atividade humana, ou trabalho; matérias-primas etc.; ferramentas ou maquinaria cada vez mais complexa". Para maiores detalhes, consultar o trabalho de Palloix, C. O processo de trabalho: do fordismo ao neofordismo. In: Tronti, Mario et alii. Processo de trabalho e estratégias de classe. Rio de Janeiro, Zahar, 1982.

Sobre a questão da subsunçāo formal do trabalho ao capital ("forma geral de todo, processo capitalista de produção") e da subsunçāo real do trabalho ao capital (modo especificamente capitalista de produção; "a subsunção real do trabalho ao capital se desenvolve em todas as formas que produzem mais-valia relativa, diferentemente da absoluta") consultar: Marx, K. Livro I, Capttulo VI. São Paulo, Ciências Humanas, 1978.

13 Entre essas estratégias, de maneira resumida, poderíamos indicar o jobenrichment, os grupos semi-autônomos e os Círculos de Controle de Qualidade, no âmbito do processo produtivo e, fazendo parte de uma estratégia mais global, a participação na gerência, como a co-gestão, o delegado sindical e os Comitês de Empresa, sendo que essa última forma já está presente em várias indústrias automobilísticas do Brasil.

Chamamos a a tenção, em relação a essas "novas" opç̄es organizacionais, que um balanço e descrição de todas essas formas "participativas" no processo de produção serão objeto de um nosso estudo à parte. É importante frisar, no entanto, que existe uma "escassez relativa de estudos que tenham como objeto os processos conflitivos mais latentes do que manifestos, mais implícitos do que explícitos, e náo necessariamente organizados, que se dão en tre o operariado e os demais setores e classes sociais. E também, a través desses conflitos mais 'surdos', que o operariado tem a oportunidade de realizar seu aprendizado político e de chegar a constituir-se em uma força socialmente significativa" (Pereira, 1979, p. 18).

140 "melhor" trabalho que conhecemos sobre organização, utilizando o método funcionalista, é o de Katz, D. \& Kahn, R.L. Psicologia social das organizaçóes. São Paulo, Atlas, 1970.

Sobre o estruturalismo weberiano, a obra que ainda continua clássica é: Etzioni, A. Antilise comparativa de organizaçóes complexas. Rio de Janeiro, Zahar, 1974.

Sobre o estruturalismo de corte mais marxista, a referência obrigatoria. é: Clegg, Stewart. The theory of power and organization. London, Routledge \& Kegan Paul, 1979.

Para um maior aprofundamento do tema, consultar, também, a obra clássica de Zwerman, W. New perspective on organizational theory; an empirical reconsideration of the marxian and the classical analysis. Connecticut, Greenwood, 1970.

No que diz respeito às u topias da desinstitucionalizaçáo radical da sociedade, é de fundamental importância a obra de Lourau, R. Andlise institucional. Petrópolis, Vozes, 1975, bem como a de Bourdet, I. \& Guillerm, A. Autogestāo: uma mudança radical. Rio de Janeiro, Zahar, 1976. 
15 A melhor cri tica que conhecemos aos métodos clássicos de pesquisa - dedutivo, indutivo e o histórico-dedutivo de Popper - é a de Feyrabend, Paul. Contra o método; esboço de uma teoria anárquica da teoria do conhecimento. Rio de Janeiro. Francisco Alves, 1977.

O método que o autor defende é a contra-indicacá, ou seja, "examinar o princípio em pormenor concreto significa tratar das contra-regras que se opóem a algumas regras comuns do empreendimento científico (...) A 'contra-regra' aconselhanos a introduzir e elaborar hipóteses que náo se ajustam a teorias firmadas ou a fatos bem estabelecidos. Aconselha-nos a proceder contra-indutivamente" (pl 39).

${ }^{16}$ TLTX foi o nome dado pelos autores à empresa pesquisada.

17 "Acreditamos que os depoimentos operários, ainda que imbuídos de representaçōes e valores característicos de todo discurso ideológico, constituem a maneira mais adequada de obtermos as informaçoses desejadas sobre as formas reais e concretas do processo de trabalho, na medida em que sto os trabalhadores os agentes diretos das operações técnicas e o controle de suas atividades é um objetivo fundamental da organização social da produção" (Pereira, 1979, p. 30).

\section{REFERENCLAS BIBLIOGRÁFICAS}

Chaur, M. Cultura e democracia. São Paulo, Moderna. 1981.

Da Matta R. et alii. A violência brasileira. Sáo Paulo, Brasiliense, 1982.

Foucault, M. História da sexualidade. Rio de Janeiro, Graal, 1977.

Graal, 1979.

Microfisica do poder. Rio de Janeiro,

Garcia, F.C. Sobre o controle, a disciplina e a puniçäo; notas teóricas para uma investigação empírica. Belo Horizonte, Face/UFMG, 1982. mimeo.

Humphrey, J. A fábrica moderna no Brasil. Revista de cultura e política. São Paulo, 2(5/6):41-57, abr./set. 1981.

Luz, M.T. As instituiçōes médicas no Brasil; instituiçáo e estratégia de hegemonia. Rio de Janeiro, Graal, 1979.

Mcntanari, M. Domínio - saber e sistema dos partidos: a propósito de Foucault e dos novos filosofos. Encontros com a civilização brasileira, Rio de Janeiro, 3(4), 73-8, abr. 1980.

Pagès, M. et alii. L'emprise de l'onganisation. Paris, Presses Universitaires de France, 1979.

Pereira, V.M.C. $O$ coração da fábrica; estudo de caso entre operários têxteis. Rio de Janeiro, Campus, 1979.

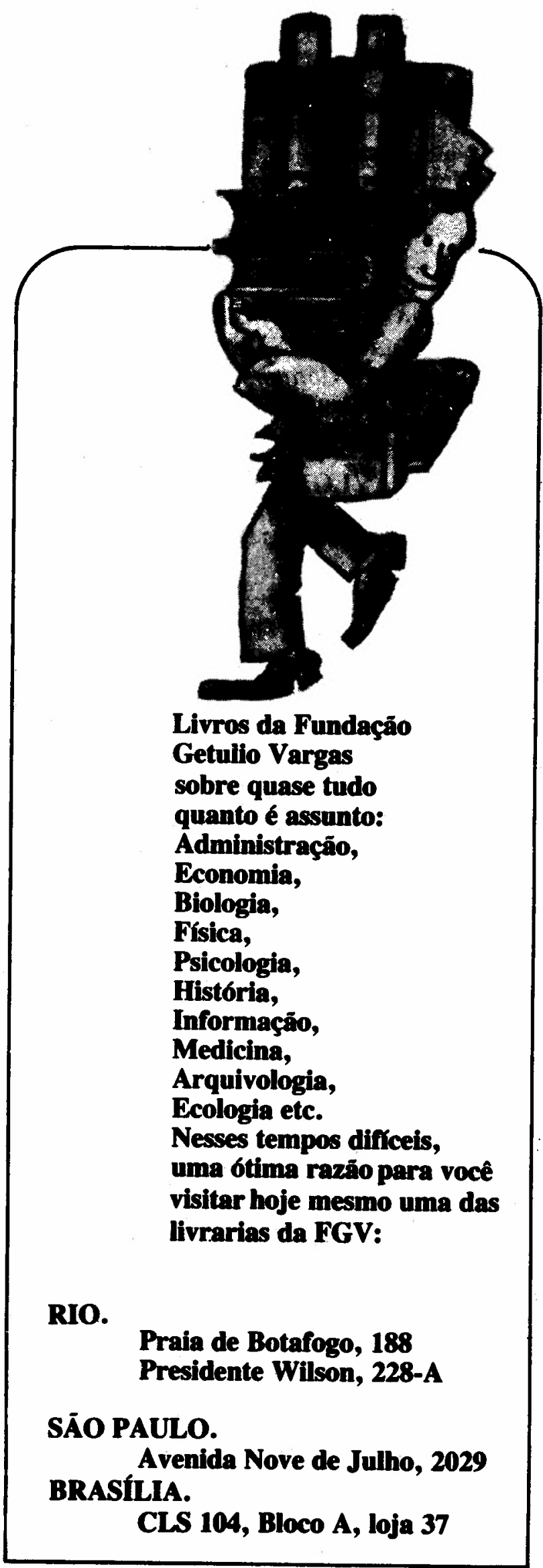

